\title{
Lifestyle and Medication Costs May Be Associated with Consequences for Adult Patient Health
}

\author{
Abrahão Afiune Neto ${ }^{\odot}$ \\ Universidade Federal de Goiás, Goiânia, GO - Brazil \\ Universidade Unievangélica, Anápolis, GO - Brazil \\ Short Editorial related to the article: The Relationship between Lifestyle and Costs Related to Medicine Use in Adults.
}

The increase in health costs can be explained by several factors, such as the aging of the population, changes in the morbidity and mortality structures of the population and the introduction of new medical technologies in the diagnosis and treatment of diseases. ${ }^{1}$

Moreover, the guarantee of the appropriate and safe use of the medications also covers clinical, economic, legal, regulatory, and cultural aspects that must be taken into account in the decision-making process in the health sector. The first study on the economic analysis of medications was published in 1979 by Bootman et al. ${ }^{2}$

In recent years, drug costs have become a threat to the sustainability of public health systems in many countries. These costs have affected other major priorities in the health sector, and these costs have not resulted in significant health indicator improvements. Medication-related economic expenses involve not only the cost of treatments resulting from inappropriate drug use but also the purchase of prescription or non-prescription drugs. ${ }^{3}$

According to the World Health Organization $(\mathrm{WHO})^{4}$ lifestyle is the set of habits and customs that can be influenced, modified, encouraged or inhibited by the prolonged process of socialization. These habits and customs include the use of substances such as coffee, alcohol, tobacco or tea, dietary and exercise habits. These substances are important and have consequences for health and are often investigated through epidemiological studies.

Unhealthy lifestyle behaviors, such as alcohol consumption, smoking, sleep disorders, and sedentary individuals, have been responsible for the development of several diseases. On the other hand, medical, diagnostic advances and modern therapeutics have been responsible for improving quality of life and longevity.

\section{Keywords}

Health Education; Drug Costs; Life Style; Exercise; Tobacco and Disorders; Alcoholism; Drug Utilization/economics.

Mailing Address: Abrahão Afiune Neto •

Rua T-38, 917. Postal Code 74223-045, Setor Bueno, Goiânia, GO - Brazil E-mail: aafiune@arh.com.br

DOI: $10.5935 /$ abc. 20190108
Unlike lifestyle, the term "quality of life" involves physical and mental well-being.

Recent studies have shown that lifestyle interventions are as effective as evidence-based medical therapies in reducing mortality. ${ }^{5}$

The reduction in mortality in the USA attributed to the decrease in risk factors, as a result of the improvement in the environmental lifestyle, reached $44 \%$, while those related to medication use were $47 \%{ }^{6}$

There is strong evidence that lifestyle changes have a major impact on the quality of life of individuals and of the population. ${ }^{7}$ Lifestyle is considered fundamental and determinant for health, mainly related to individual behavior (eating habits, stress management, preventive behavior and physical activity). ${ }^{8}$ Regarding physical activity, the WHO states that physical inactivity is among the four main causes of mortality worldwide. ${ }^{9}$

The article by Fernandes et al., ${ }^{10}$ published in 2018 in Arquivos Brasileiros de Cardiologia, evaluated the association of some quality of life-related items with medication costs, an idea that has validity, as it is currently thought-provoking. However, even though a multivariate analysis was performed, it is difficult to establish a causal association. Issues such as quality of sleep and alcohol consumption were associated with costs, while physical activity and smoking did not show an independent association.

The balance of positive and negative variables makes an overall conclusion regarding lifestyle and cost of medications indeterminate. Since it is difficult to mechanistically justify the association with some variables, but not with others, we conclude these associations may result from a residual confounding effect.

Therefore, we consider this article ${ }^{10}$ brings reflections, but this question cannot be defined, leaving it in the open for future studies. It is important to have monetary costs in mind in relation to decision-making. But whether lifestyle is the focus to rationalize the system has yet to be defined. First, this causal association is doubtful; second, there are more direct and predictable ways of reducing costs; and, finally, the economic reasoning will not be a determinant of the lifestyle recommendation or quality of life, which should be sought regardless of the costs. 


\section{Short Editorial}

\section{References}

1. Médici AC. Economia e financiamento do setor saúde no Brasil: balanços e perspectivas do processo de descentralização. São Paulo: Faculdade de Saúde Pública da USP; 1994.

2. Bootman JL, Wertheimer A I, Zaske D, Rowlaud C. Individualizing gentamicin dosage regimens on burn patients with gram-negative septicemia: a cost-ben efit analysis. J Pharm Sci. 1979;68(3):267-72.

3. Ford ES, Ajani UA, Croft JB, Critchley JA, Labarthe DR, Kottke TE, et al. Explaining the decrease in U.S. deaths from coronary disease, 1980-2000. N Engl J Med. 2007;356(23):2388-98.

4. WHO Centre for Health Development (Kobe,Japan);2004. A glossary of terms for community health care and services for older persons. Kobe,Japan [WHO Kobe Centre ageing and health Technical Report;v.50]. Available from: http:www.who.int/íris/handle/10665/68896

5. Danaei G, Ding EL, Mozaffarian D, Taylor B, Rhem J, Murray CJ, et al. The preventable causes of death in the United States: comparative risk assessment of dietary, lifestyle, and metabolic risk factors. PLoS Med. 2009;6(4):e1000058.
6. Guyatt GH, Ferrans CE, Halyard MY, Revicki DA, Symonds TL, Varricchio $C G$, et al.Exploration of the value of healthy-related quality of life information from clinical research and int clinical practice. Mayo Clin Proc. 2007;82(10):1229-39

7. Blanchard CM, Courneya KS, Stein K,American Cancer Society's SCS.II. Cancer Survivors' Adherence to Lifestyle Behavior Recommendations and Associations With Health-Related Quality of Life: Results From the American Cancer Society's SCS-II. J Clin Oncol. 2008;26(13):2198-204.

8. Nahas MV. Atividade física, saúde e qualidade de vida. 6.ed. Londrina: Madiograf; 2013. p. 24-25.

9. World Health Organization.(WHO). Global health risks: mortality and burden of disease attributable to selected major risks. Geneva: World Health Organization;2009. [Cited in 2016 April 16] Available from: http://www.who. int/healthinfo/global_burden_disease/GlobalHealthRisks_report_full.pdf.

10. Fernandes RA, Mantovani AM, Codogno JS, Tury-Lynch BC, Pokhrel S, Anokye $\mathrm{N}$. The relationship between lifestyle and costs related to medicine use in adults. Arq Bras Cardiol. 2019; 112(6):749-755. 